\title{
Yeast (Saccharomyces cerevisiae) Glucan Polysaccharides - Occurrence, Separation and Application in Food, Feed and Health Industries
}

\author{
Stefan Kwiatkowski and Stefan Edgar Kwiatkowski
}

Additional information is available at the end of the chapter

http://dx.doi.org/10.5772/48100

\section{Introduction}

Energy is stored in plants in form of carbohydrates, including sucrose (i.e., saccharose, a disaccharide) and starch (a polysaccharide). Sucrose and starch are derived from glucose, the product of carbon dioxide and water in photosynthesis. These carbohydrates are not only essential as energy supplies in food and animal feed, but in recent years have also been tapped as a renewable fuel energy source by the fuel ethanol industry. Some plants, like sugar cane or sugar beet, produce juice rich in sucrose, a mixed glucose-fructose disaccharide. Brewer's yeast (Saccharomyces cerevisiae) can directly ferment sucrose into ethanol, whereas starch, like that found in corn or potatoes, must first be hydrolyzed, to glucose or fermentable glucose oligosaccharides by an enzyme (e.g., amylase) before fermenting into ethanol. Cellulose, structural polysaccharides in plants, is even more difficult to hydrolyze to glucose. To obtain fermentable sugars, cellulose-containing plant material is usually subjected to a physicochemical pretreatment followed by enzymatic hydrolysis with cellulases. Such pretreatment processes are expensive and not yet used commercially on a large scale.

Because sugar and starch are major components of human food, and cellulose is the principal component of ruminant feed, their large-scale use in fuel alcohol production is already affecting food prices in the world. Brazil began producing fuel ethanol from sugar cane 36 years ago and in 2010 supplied enough ethanol to sell gasoline containing $25 \%$ ethanol throughout the country. Similarly, a large-scale, government sponsored program of fuel ethanol production from starch, using maize as its source, was started in the United States in 2007. This industry has created vast quantities of yeast byproducts; including a commercial-scale source of yeast extract, yeast glucose and mannose polysaccharides. Sugar cane juice and sugar beet juice fermentations are especially convenient for yeast collection, 
because the post-fermentation solution does not contain solids such as non-fermentable residues, like those produced during corn mash fermentation.

The yeast cell wall contains three major constituents: glucan (glucose polysaccharide), mannan (mannose polysaccharide) and a protein fraction. The separation of these natural polymers is simple and inexpensive. However, it is difficult and expensive to obtain more than $65 \%$ pure fractions and, therefore, these components are produced and sold at these low levels of purity. Their largest commercial application has been as animal feed nutritional supplements (see, http://www.Alltech.com).

There are three well known types of glucose polysaccharides in yeast: poly- $(1 \rightarrow 3)(1 \rightarrow 6)-\beta-$ D-glucopyranose - commercial name: yeast $\beta$-D-glucan, yeast glucan; poly- $(1 \rightarrow 4)-\alpha$-D-

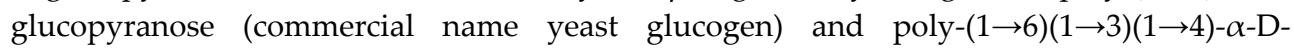
glucopyranose a recently "rediscovered" polysaccharide (Arvindecar \& Patil, 2002) yet without a commercial name. The prefix "poly" informs about the polymeric nature of the material built of D-glucose cyclic monomers (D-glucopyranose rings) and the letter D informs that glucose belongs to the group of naturally occurring plant sugars with $D$ stereochemistry. The letter $\alpha$ or $\beta$ refers to the configuration of the glycosidic bonds between the C- 1 of a nonreducing ring and the C- 6 of a reducing ring or the C- 1 of a nonreducing ring and the C-3 of a reducing ring (see Fig. 1, Lindhorst 2003). Figure 1 shows structures of $\beta$-D-glucopyranose isomer with a $\mathrm{C}-1 \mathrm{OH}$ group in the $\beta$ position (solid line) or a $\mathrm{C}-1 \mathrm{OH}$ group in the $(\alpha)$ position (dotted line). Penta- $(1 \rightarrow 6)(1 \rightarrow 3)-\beta$-D-glucopyranose drawing shows the location of all $\mathrm{OH}$ groups, glycosidic bonds and glucopyranose rings within the structure. (The hydrogen atoms attached to carbon atoms are not shown.)

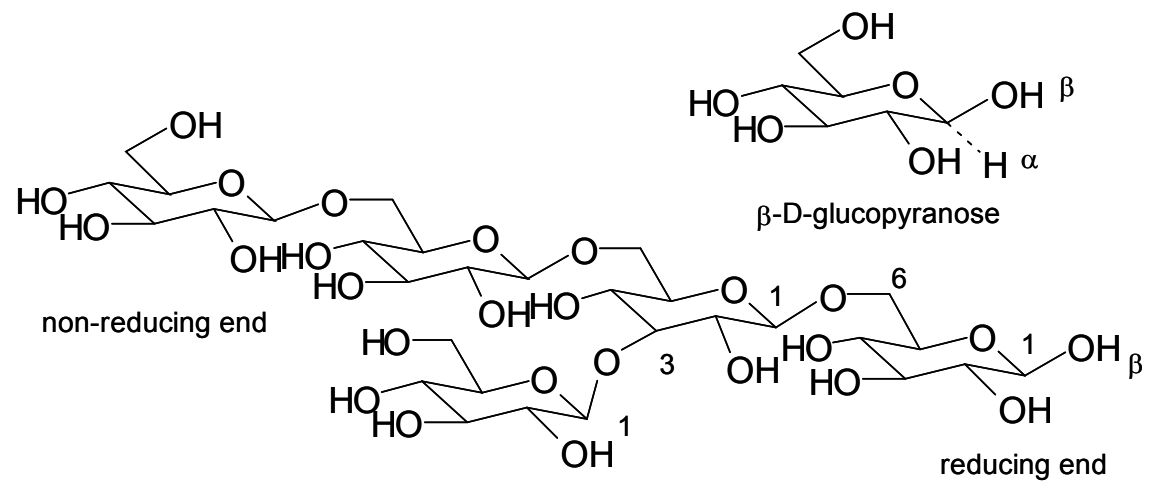

Fig. 1

non-reducing end

\section{Figure 1.}

Solving polysaccharide structure is not simple. At first, a sample needs to be homogenous and $98-99 \%$ pure. Different separation techniques (i.e., size exclusion chromatography, affinity (lectin) chromatography and in some cases high performance liquid chromatography (HPLC) are suitable for the purification of water or solvent soluble 
samples. Spectroscopic methods, such as ${ }^{1} \mathrm{H}$ and ${ }^{13} \mathrm{C}$ nuclear magnetic resonance (NMR) 1D/2D and mass spectrometry (MS) combined with chemical treatments of the sample, can provide further clues about the kind, sequence and ratios of the monosaccharides present, the type of bonds ( $\alpha$ - or $\beta$-) between individual sugars, the branching points and reducing and non-reducing ends, and its molecular weight.

The experimental procedures that are most frequently used in the process of solving the polysaccharide structure are:

\section{Sample purification}

A solid, crude, non-homogenous, polysaccharide must be solubilized in an appropriate solvent (water) or, in the case of insoluble polysaccharides, it must be subjected to chemical or enzymatic degradation (with minimal damage to the original structure) to reduce the polymer size which then allows the sample to become soluble. Sample solubilization makes the use of various chromatographic techniques (i.e., ion exchange chromatography, size exclusion chromatography, affinity-chromatography, sorbent-liquid chromatography) for sample fractionation and purification, possible.

\section{Composition analysis}

Complete acid hydrolysis is used to cleave all glycosidic bonds in the polysaccharide and to release D-glucose as a single product (in the case of glucans), which is then identified by comparison to a D-glucose standard.

3. Methylation linkage analysis

All of the polysaccharide hydroxyl $(\mathrm{OH})$ groups are methylated using an excess of methylation reagent (dimsyl sodium followed by methyl iodide). Obtained this way, the fully O-methylated derivative is then subjected to acidic hydrolysis of all glycosidic linkages. The released O-methylated derivatives of D-glucose: 2, 3, 4, 6-O-tetramethyl-Dglucose; 2, 3, 4-O-trimethyl-D-glucose; 2, 4-O-dimethyl-D-glucose are identified and quantified using HPLC/MS and appropriate standards. In the case of pentasaccharide (Fig.1) the ratios of the methylation products would be 2:2:1.

\section{Spectroscopy}

Finally, ${ }^{1} \mathrm{H}$ and ${ }^{13} \mathrm{C}$ NMR and M S are used to establish the sequence of glucopyranose rings, the position of branching points, the number of non-reducing ends and the nature of glycosidic bonds ( $\alpha$ or $\beta$ ). If the polysaccharide contains repeating sequences, their ratios can be also established.

\section{Enzymatic action}

Glycosidases and lectins of known specificity are applied to confirm glucose oligosaccharide structures, from which the complete polysaccharide architecture can be deduced.

The Complex Carbohydrates Research Center located at The University of Georgia (http://www.ccrc.uga.edu) offers services covering all of the aspects of the polysaccharide structural assignments. 


\section{Fungal and yeast cell wall, D-glucose homo- and hetero- polysaccharides}

Fungi constitute an independent evolutionary group of eukaryotic organisms equal in rank to that of plants or animals. They can excrete hydrolytic enzymes that break down biopolymers (polysaccharides and proteins) of plant or animal origin and use sugars and/or amino acids for their nutrition. Yeast is a single-cell fungus and the Saccharomyces cerevisiae species (baker's or brewer's yeast) has been utilized by people from early human civilization in food and beverage preparation. Mushrooms are fungal fruiting bodies; edible mushrooms are taste improving, "healthy" food ingredients that are very popular on European and Asian menus. Extracts and dried powders made by processing "medicinal mushrooms" are important ingredients of traditional Eastern medicinal remedies.

Fungal cell walls are made of polysaccharides. Chitin, a homopolymer of $(1 \rightarrow 4)-\beta-\mathrm{D}-\mathrm{N}$ acetylglucosamine and various glucans (homopolymers of D-glucose, with $\alpha$ - or $\beta$ glycosidyl linkages between C-1 and C-2, C-3, C-4 and C- 6 of glucopyranose rings) are the most frequently found building blocks used by nature in construction of the cell wall that separates the fungus from the environment. In yeast, $\alpha$ - and $\beta$-glucans and $\alpha$-mannan are the major polysaccharides (chitin is present at $1-2 \%$ ) that are utilized in cell wall construction. Their ratio changes with yeast strain and growth stage and is dependent upon growth conditions including oxygen and nutrient availability and the temperature and $\mathrm{pH}$ of the medium (Stewart \& Russell, 1998). Table 1 shows the average abundance of yeast cell wall components.

\begin{tabular}{|c|c|}
\hline Component & $\begin{array}{c}\text { Cell wall mass } \\
(\%, \text { dry weight })\end{array}$ \\
\hline$(1 \rightarrow 3)-\beta$-D-glucan & $50-55$ \\
\hline$(1 \rightarrow 6)-\beta$-D-glucan & $5-10$ \\
\hline$(1 \rightarrow 4)-\alpha-(1 \rightarrow 3)-\beta$-D-glucan & $3-7^{*}$ \\
\hline Mannoprotein complex & $35-40$ \\
\hline Chitin & 2 \\
\hline
\end{tabular}

Mannan structure can be represented by the following formula: poly- $(1 \rightarrow 2)(1 \rightarrow 3)(1 \rightarrow 6)-\alpha$-D-mannopyranose. This polysaccharide is built out of a long backbone chain of $(1 \rightarrow 6)-\alpha$-D-mannopyranose rings with short mannopyranose chains (one to four rings long, connected through $(1 \rightarrow 2)$ and $(1 \rightarrow 3)$ - $\alpha$-glucoside bonds (Ballou, 1980).

Table 1. The cell wall components of Saccharomyces cerevisiae (Klis et al. 2002; Kath \& Kulicke, 1999; Lessage \& Bussey, 2006; Kwiatkowski et al., 2009)

The yeast cell wall forms a border that defines the yeast cell's dimensions and separates its organelles from the negative influences of the environment. The individual constituents of the cell wall connect to each other by covalent bonds forming a single supra-molecular biopolymer. To find the nature of these connections, as well as the individual polysaccharides structures, all of the architectural elements must be dissected, solubilized, purified and analyzed. In this process it is almost impossible not to damage particular structural elements and to afterwards distinguish between the original components of the 
cell wall and soluble polysaccharides that could be present in the cytoplasm or might be trapped (physically absorbed) within cell wall. More than 50 years of research were required to establish the structure of the major, high molecular weight yeast homo-polysaccharides (Bacon \& Farmer, 1969; Aimaniada et al., 2009).

The $(1 \rightarrow 3)-\beta$-D-glucan and $(1 \rightarrow 6)-\beta$-D-glucan form a single structure in which the $(1 \rightarrow 3)-\beta-$ D-glucan forms the backbone chain with $(1 \rightarrow 6)-\beta$-D-glucan branches that are attached to branching glucopyranose rings at C-6 (Lessage \& Bussey, 2006). The $(1 \rightarrow 3)-\beta$-D-glucan chains form triple helix tridimensional structures with spring-like mechanical properties, responsible for the yeast cell wall's strength (Klis et al., 2002) and its ability to absorb toxins (Yiannikouris et al., 2004). The $(1 \rightarrow 6)-\beta$-D-glucan is a linker between $(1 \rightarrow 3)-\beta$-D-glucan, chitin and mannoproteins (Kaptein et al., 1999; Kollar et al., 1997) that stabilizes the whole structure and is the main cause of yeast cell wall insolubility. The properties and role of a mixed (1 $\rightarrow 4)$ - $\alpha$ - $(1 \rightarrow 3)-\beta$-D-glucan from yeast cells will be discussed in section 3 of this chapter.

Mannoproteins are mostly located on the outside surface of the cell wall (Osumi, 1998). They play a sensory function for nutrients and chemical and bacterial/viral toxins, actively participate in the transport of nutrients and metabolites through the cell wall, and also participate in mating (Klis et al., 2002; Stewart \& Russell, 1998). Some cell wall enzymes such as glucanase, mannanase, invertase, alkaline phosphatase and lipase are mannoproteins (Stewart \& Russell, 1998) that hydrolyze nutrients and participate in the reconstruction of cell polysaccharides during cell growth and budding. Cell wall mannans are connected with cell wall glucans via covalent bonds, but they can be released under action of an alkaline medium in which they are perfectly soluble. The process of separating yeast cell wall glucans (which stay as an insoluble fraction) from yeast mannans is used on an industrial scale (Sedmak, 2006). The soluble, mannan-rich fraction, can be added back to the cell wall which contains only $10-17 \%$ mannan by weight, to increase the content of mannan to $30 \%$ by weight. Such a product is sold by Alltech Inc. under the name of Actigen ${ }^{\mathrm{TM}}$ to the animal nutrition industry.

The small fraction of chitin present in yeast cell wall is primarily located in the scar rings around buds in budding yeast and secures closure of the gaps in the mother cell and the departing daughter cell (Lessage \& Bussey, 2006; Stewart \& Russell, 1998).

\section{3. $\alpha$-D-glucans from baker's yeast (Saccharomyces cerevisiae)}

The role of $(1 \rightarrow 3)-\beta$-D-glucan in the maintenance of yeast cell wall shape and rigidity (Lessage \& Bussey, 2006; Klis, et al. 2006) and (1 $\rightarrow 6)-\beta$-D-glucan as a polysaccharide that links together all of the cell wall polysaccharides (Aimaniada et al., 2009; Kollar et al., 1997) is well documented and has been reviewed by Lessage \& Bussey (2006) and Klis et al. (2002). The presence of starch-like, "alkali-soluble glycogen, "an "energy storage polysaccharide" in cell cytosol, and "difficult to dissolve acid-soluble," glycogen like $(1 \rightarrow 4)-\alpha$-D-glucan in the cell walls of Saccharomyces cerevisiae grown aerobically, was frequently mentioned in early yeast literature (Grba et al., 1976). The two forms of glycogen synthetase have also been identified (Rothman-Denes \& Cabib, 1970; Lille \& Pringle, 1980) but the yeast literature is still treating the "difficult to dissolve" $\alpha$-glucan as physically adsorbed cytosol glycogen, 
trapped within yeast cell wall, and not as an independent component attached by a covalent bond to the other cell wall polysaccharides. In 1973, Manners et al. reported: " $\beta-1$, 6-glucan purified after acid extraction had to be exhaustively treated with $\alpha$-amylase and still showed the presence of glucose and maltose in paper chromatographic analysis, along with gentiobiose and higher gentiooligosaccharides," which are $(1 \rightarrow 4)$ - $\alpha$-D-glucan oligosaccharides formed during enzymatic hydrolysis of the mixed $\alpha, \beta$-glucan from the yeast cell wall.

The $\alpha$-glucan content in the yeast cell wall is reported to vary from as little as $1 \%$ (Lille \& Pringle, 1980) to as much as $29 \%$ (Sedmak, 2006) of the dry weight, depending upon the nutritional status of the cells, the method of isolation, the method of analysis and the phase of growth during which the cells were harvested (Lille \& Pringle, 1980). Spectrophotometric analysis of soluble glycogen can be run directly on a water extract, and if properly done, yields reliable results (Quain, 1981). Quantitative analysis of "insoluble" glycogen requires additional, enzymatic release of glucose from its mixed polysaccharide with $\beta$-glucan (see, http://www.megazyme.com). The industrially produced brewer's yeast described in Sedmak's US patent application (Sedmak, 2006) contains glucans $(\alpha+\beta)$ at $28.9 \%$ dry weight, which includes $12.4 \% \alpha$-glucan. Hydrolysis of these water-insoluble cells with alkaline protease solubilizes the mannoprotein complex and yields water-insoluble cell wall polysaccharides (including $\alpha$-glucan) that contain $54.5 \%$ dry weight of glucans with more than half of the total weight $(29.2 \%)$ as $\alpha$-glucan.

Arvindekar and Patil (2002) proposed an explanation for the presence of $\alpha$-glucan in the insoluble fraction from yeast cell walls, which has been described by others as "difficult to wash away" yeast glycogen (Gunia-Smith et al., 1977; Manners \& Fleet, 1976). They found that the ratio of "soluble" to "insoluble" glycogen in different strains of Saccharomyces cerevisiae is in the range of 1:2.5-1:3. When the insoluble fraction was digested with purified lyticase, which possessed only $(1 \rightarrow 3)-\beta$-D-glucan hydrolyzing activity and no $(1 \rightarrow 6)-\beta$-Dglucan or $(1 \rightarrow 4)$ - $\alpha$-D-glucan hydrolyzing activities, all of the material dissolved. The affinity chromatography of the solution on a Concanavalin A (ConA) column retained a fraction that contained mixed $(1 \rightarrow 4)-\alpha-(1 \rightarrow 6)-\beta$-D-glucan polysaccharide. The eluent contained exclusively $(1 \rightarrow 3)-\beta$-D-glucan oligosaccharides. When the $(1 \rightarrow 4)-\alpha$-D-glucan-rich fraction was released from its binding with ConA and treated with amyloglucosidase followed by dialysis to remove glucose, subjecting the resulting solution to affinity chromatography on a ConA column showed none of the material was retained. The material recovered from the solution was then proved to be pure $(1 \rightarrow 6)-\beta$-D-glucan. These simple experiments showed that the "insoluble glycogen" from yeast cell wall is a mixed glucan in which $(1 \rightarrow 4)-\alpha$-Dglucan is connected to $(1 \rightarrow 3)-\beta$-D-glucan through a $(1 \rightarrow 6)-\beta$-D-glucan link. The structure of this mixed yeast cell wall $(1 \rightarrow 4)-\alpha-(1 \rightarrow 6)-\beta-(1 \rightarrow 3)-\beta$-D-glucan was confirmed by our ${ }^{1} \mathrm{H}$ NMR study (Kwiatkowski et al., 2009) and methylation analysis done at CCRC.

We used yeast cell wall $\alpha$-glucan (prepared in our laboratory) in the development of the enzyme linked immunosorbent assay (ELISA) for yeast cell wall quantitative analysis in a complex polysaccharide matrix (Moran et al., 2011). The antigen was prepared in two stages. 
At first a sample of cell wall $(1 \rightarrow 4)$ - $\alpha$-D-glucan (fraction $50-100 \mathrm{kDa}$ separated with the help of an ultra centrifugal filter (Aldrich Inc.) was oxidized mostly at the C-6 carbons using the Albright-Goldman oxidation reagent (Albright \& Goldman, 1967; Zekovic et al., 2006) which converted the $-\mathrm{CH}_{2} \mathrm{OH}$ groups into aldehyde groups $-\mathrm{CH}=\mathrm{O}$ in glucopyranose rings. The reaction produced a highly cross-linked polymer, with internal acetal bonds, but still well soluble in DMSO (dimethyl sulfoxide) and water, which was coupled to a bovine serum albumin (BSA), yielding the antigen (glucan-BSA conjugate). To restore the original $\alpha$ glucan structure, but with $-\mathrm{CH}_{2}-\mathrm{NH}-\mathrm{BSA}$ groups instead of $-\mathrm{CH}_{2}-\mathrm{OH}$ groups at the glucan's C-6 carbon, the conjugate C-6 imino (-CH=N-BSA) groups were reduced with sodium cyanoborohydride (Baxter \& Reitz, 2002). Sodium dodecyl sulfate (SDS) polyacrylamide gel electrophoresis (PAGE) of the conjugate indicated the presence of significant quantities of free BSA (line at $66 \mathrm{kDa}$ ) together with the glucan-BSA conjugate of molecular size between 100 and $175 \mathrm{kDa}$. To remove the excess BSA, the concentrated solution of the conjugate was washed with water of $\mathrm{pH} 7.0,8.5$ and 4.5 using an ultra centrifugal filter with the $50-\mathrm{kDa}$ membrane. This "purified" conjugate was used then in rabbit immunization. We found that the rabbit polyclonal antibodies were very sensitive to yeast cell wall $\alpha$-glucan, but (as expected) they were also cross-reactive with BSA. To delete this activity we synthesized the BSA-coated affinity phase (Moran et al., 2011) and removed antibodies specific to BSA from the crude fraction of polyclonal rabbit anti- $\alpha$-glucan antibodies. We also found that antibodies grown against this $\alpha$-glucan polysaccharide did not recognize any commercially available starch or glycogen samples, including yeast glycogen. Such specificity confirms structural differences between the cell wall and the cytosol $\alpha$-glucans from Saccharomyces cerevisiae. Because of the high specificity and very low cross reactivity of the "purified" rabbit antibodies with soy proteins and corn carbohydrates, the ELISA cell wall assay detects and quantifies samples of yeast cell wall down to $50 \mathrm{~g} / \mathrm{ton}$ of feed (Moran et al., 2011). A similar assay was used for quantification of $\alpha$-D-glucanprotein complex in mushrooms with immunomodulatory activity (Hirotaka et al., 2007).

What is the role of this polysaccharide in yeast cell life? Some remarks in the literature point to its role in yeast flocculation (Patel \& Ingledew, 1975), acting as part of a possible killer toxin receptor (Hutchkins \& Bussey, 1983) and as being sensitive to environmental conditions and changes in medium (Slaughter \& Nomura, 1992; Dake et al., 2010; Jadhav et al., 2008). The cell wall bound $\alpha$-glucan from fission yeast Schizosaccharomyces pombe has been studied in detail (Villar-Tajadura et al., 2008; Vos et al., 2007 ; Garcia et al., 2006; Grün et al., 2005), and systematic identification of the genes affecting glycogen storage in the yeast Saccharomyces cerevisiae was attempted (Wilson et al., 2002). Unfortunately, the presence of the two different pools of glycogen was not addressed. One of the possible functions of bound $\alpha$-glucan might be the temporary formation of mixed $\alpha, \beta$-glucan oligosaccharides that become soluble in cytoplasm and can be transported inside the cell wall where the $\beta$ glucan fragment is used in the construction of insoluble yeast cell wall $\beta$-glucan polysaccharide.

Is it possible that $\alpha$-glucan polysaccharides from yeast or mushrooms can have medicinal properties? There is no literature concerning the medicinal properties of $\alpha$-glucan as a 
separate fraction of the yeast cell wall, which is a consequence of acknowledging it as part of an energy storage cellular polysaccharide-yeast glycogen. Bioactive components containing $\alpha$-glucan, mixed $\alpha, \beta$-glucan or $\alpha$-glucan-protein complexes are known to be present in extracts from the fruiting bodies of edible medicinal-mushrooms. Like in the case of many other traditional herbal remedies, it is difficult to separate the single bioactive component's ( $\alpha$-glucan) bioactivity from the activities of the other components of the extract, and in some cases, early assignments were incorrect.

Mushrooms with medicinal activities that contain extractable $\alpha$-glucan in their fruiting bodies, belong to one of two phyla: Ascomycota or Basidiomycota. Hot-water extracts from Peziza vesiculosa (Ohno et al., 1985; Suzuki et al., 1982) and Cordyceps chinensis (Yan et al., 2011; Holliday \& Cleaver, 2008; Khan et al., 2010; Liu et al., 2006; Kiho et al., 1993; Kiho et al., 1996; Li et al., 2006), which are both Ascomycota, have been shown to have antitumor and anti-diabetic activities. The linear $\alpha-(1 \rightarrow 4)$-D-glucan is less active than $\alpha-(1 \rightarrow 4)(1 \rightarrow 6)$-Dglucan with 1 to 6 branches on the backbone $1 \rightarrow 4$ chain with a ratio of 1:8. The biological activity of glycogen-like polysaccharides was found to be molecular-size dependent with smaller $\sim 9.5 \mathrm{kDa}$ molecules being active, whereas 14-24 kDa molecules were not (Kakutani et al., 2007).

More is known about edible mushrooms belonging to Basidiomycota which contain both: $\alpha$ and $\beta$-glucans in their fruiting bodies (Rop et al., 2009). Hot-water extracts from Peziza vesiculosa show antitumor activity (Ohno et al., 1985; Suzuki et al., 1982) and extracts from Grifola frondosa (Maitake) show glucose suppression (Tanaka et al., 2011) and antidiabetic (Lei et al., 2007) activities. Extracts (Shida \& Matsuda, 1974) from Lentinus edodes (Shiitake) stimulate the immune system (Shah et al., 2011; Terakawa et al., 2008) and possess antibacterial, antiviral (Mach et al., 2008) and anticancer properties (Shida \& Matsuda, 1974; Hyodo et al., 2005; Shah et al., 2011). Extracts from Tricholoma matsutake (Matsutake) show antitumor (Ebina et al., 2002) and immunomodulatory (Hirotaka et al., 2007; Hirotaka et al., 2005) activities. Extracts (Smiderle et al., 2010) from Agaricus bisporus (Portobello) inhibit breast cancer cell proliferation (Grube et al., 2001) and stimulate the immune system (Ren et al., 2008; Koppada et al., 2009). A glycogen-like polysaccharide from Portobello mushrooms potently activated macrophages, stimulating TNF- $\alpha$ production and phagocytosis of RAW264.7 cells (Kojima et al., 2010). Extracts from Pleurotus ostreatus (Oyster mushroom) show antiproliferative and proapoptotic activities on colon cancer cells (Lavi et al., 2006). Pholiota nameko (Butterscotch mushroom), which has been in use as a major component of miso soup in Japan, shows antinflammatory activity (Li et al., 2008). In Asian and European culinary traditions, meals containing these mushrooms are believed to be healthy and to heal a variety of ailments.

Whether $\alpha$-glucan from yeast cell walls can contribute to the known medicinal activities of various extracts from whole yeast is still an open question. Newly developed, simple methods for producing large quantities of this material (Kwiatkowski et al., 2009; Moran et al., 2011) should stimulate new research in this area.

The abundant literature regarding bioactivity of the whole yeast cell wall and its extracts rich in $\alpha$-mannoprotein or $\beta$-glucan, will be discussed in sections 4,5 and 6 of this chapter. 


\section{Baker's yeast cell wall $\beta$-D-glucan/ $\alpha$-mannoprotein complex}

Yeast cell wall biogenesis was studied by Smits (Smits et al, 2001) who found that "The yeast cell wall forms a border that defines the yeast cell's dimensions and separates its organelles from the negative impact of the environment. All of the individual constituents of a yeast cell wall connect to each other by covalent bonds forming a single supra-molecular biopolymer". The $(1 \rightarrow 3)(1 \rightarrow 6)-\beta$-D-glucan and the $(1 \rightarrow 2)(1 \rightarrow 3)(1 \rightarrow 6)-\alpha$-D-mannan/protein complexes (Vinogradov et al., 1998) are the major components of this supra-molecular biopolymer (Lessage \& Bussey, 2006; Kath \& Kulicke, 1999). They connect to each other by a covalent bond the nature of which is still under investigation (Kaptein et al., 1999; Kollar et al., 1997). In the process of yeast cell wall isolation the cell wall is first cracked open, with the help of physical, chemical and/or enzymatic treatments (Kath \& Kulicke, 1999) and then separated from the soluble yeast cell components by centrifugation (Sedmak, 2006; Jamas et al., 1998). The concentrated yeast cell wall solids containing $\sim 30 \%$ dry weight material are then spray-dried. The resulting product is a fine powder with a light tan color. The cell wall polysaccharides can be separated from each other by alkaline extraction, which solubilizes the $\alpha$-mannoprotein fraction and leaves $\beta$-glucan particles in suspension. The $\beta$-glucan particulate can be separated from the soluble $\alpha$-mannoprotein fraction by centrifugation and spray-dried to yield light, yellow colored, fine powder, free of any smell or taste, containing $\sim 65 \% \beta$-glucan. The $\alpha$-mannoprotein solution can then be concentrated by using membrane ultrafiltration and spray-dried to produce a light brown, "mannan rich fraction" with $\sim 40 \%$ by weight of $\alpha$-mannan. Yeast cell walls as well as both fractions of polysaccharides are produced on a large scale and have practical applications as animal feed nutritional supplements. Furthermore, this yeast cell wall preparation, sold by Alltech Inc. under the name of Bio-Mos ${ }^{\circledR}$, was proved (in more than 600 feeding trials) to have a positive impact on the immune system of livestock (Baurhoo et al., 2009; Yang et al., 2008; Rosen et al., 2007; Jacques \& Newman, 1994; Morrison et al., 2010) fish (Dimitroglu et al., 2009), and companion animals (Swanson et al., 2002) when added to feed at the rate of $0.5-2.0 \mathrm{~kg} / \mathrm{ton}$. Bio-Mos ${ }^{\circledR}$ contains $\sim 17 \%$ of $\alpha$-mannan, which is possibly its bioactive component. An improved form of Bio-Mos ${ }^{\circledR}$ is marketed by Alltech Inc. under the name Actigen $^{\mathrm{TM}}$. This improved product contains $30 \% \alpha$-mannan and is manufactured, by mixing yeast cell wall with a mannan-rich fraction. Actigen ${ }^{\mathrm{TM}}$ product is four times more active than Bio-Mos ${ }^{\circledR}$ ( $\sim 13 \%$ of it is soluble and therefore, better available to interaction with microbes and animal gut) and its application rate of 250-500 g/ton approaches that of antibiotics. Alpha-Dmannans have a "brush like" structure built out of $\alpha-(1 \rightarrow 2)$ - and $\alpha-(1 \rightarrow 3)$-D-mannopyranose branches, 1 to 5 rings long (brush hair), which are attached to a $~ 120$-ring-long $\alpha-(1 \rightarrow 6)$-Dmannopyranose chain, the brush handle (Vinogradov et al., 1998). This structure creates a specific combination of various functionalities that also involve protein conjugates. It can fit with various receptors present on the walls of animal digestive tracts (Mansour \& Levitz, 2003) and with the receptors on the membranes of pathogenic bacteria (Wellens et al., 2008). Alpha-D-mannan/protein-conjugates are involved in interactions with animal immune systems and as a result enhance immune system activity (Wismar et al., 2010) and contribute to animal antioxidant and antimutagenic defenses (Krizkova et al., 2006). Immune system 
strength, blockage of bacterial adhesion to the gut and modification of the gut structure contributes to improved survival and better growth in young animals. The second major yeast cell wall polysaccharide, $(1 \rightarrow 3)(1 \rightarrow 6)-\beta$-D-glucan, might also contribute to yeast cell wall biological properties (section 5 of this chapter), but its major role in animal nutrition is its ability to bind mycotoxins and detoxify animal feed. The $(1 \rightarrow 3)(1 \rightarrow 6)-\beta$-D-glucan is a part of the cell wall's "triple helix tridimensional structure, with spring-like mechanical properties, responsible for yeast cell wall strength and ability to absorb toxins" (Yannikouris et al., 2004) (see section 2, this chapter). Toxins occurring in plant-derived animal feed belong to one of two groups. Mycotoxins (the first group) are the by-products of the secondary metabolism of pathogenic fungi (Bennet \& Klich, 2003), whereas chemical toxins (the second group) are incorporated into plant tissue as a result of plants metabolizing agrochemicals from the soil or water used for irrigation (McLean \& Bledsoe, 1992). Some of the most problematic mycotoxins in causing human or animal diseases (i.e., aflatoxin, citrinin, ergot alkaloids, fumonisins, ochratoxin A, patulin, trichothecenes and zeralenone; Smith et al., 1995) can be absorbed by yeast cell wall $\beta$-glucans (Yiannikouris et al., 2004; Yannikouris et al., 2006). A mixture of cell wall $\beta$-glucan with clay (bentonite) sold as Mycosorb ${ }^{\circledR}$ by Alltech Inc. offers a spectrum of mycotoxin absorption superior to that of yeast cell wall glucans alone and also absorbs heavy metals (Brady et al., 1994). As in the case of Bio-Mos ${ }^{\circledR}$ a multitude of feeding trials have demonstrated the efficacy of Mycosorb ${ }^{\circledR}$ as an animal feed detoxifier using companion animals (Leung et al., 2006), horses (Raymond et al., 2003), pigs (Kogan \& Kohler, 2007) and poultry (Dvorska et al., 2003; Karaman et al., 2005; Valarezo et al., 1998).

The whole yeast Saccharomyces cerevisiae grown in a medium containing inorganic selenium (Demirici \& Pometto, 1999; Demirici et al., 1999; Mapelli et al., 2011) is used to produce yet another yeast-based human/animal nutritional supplement SelPlex® (Alltech Inc.). To maintain healthy metabolism, the human body requires $17 \mu \mathrm{g}$ of selenium a day. Dietary selenium is used to synthesize selenocysteine (in liver) and is then incorporated into more than 25 Se-containing enzymes that play important roles in body's defense against free radical species (Tapiero et al., (2003) and in many other cellular processes including the generation of energy in mitochondria (Rayman, 2000). Because yeast does not possess genes that control selenium metabolism (Rodrigo, 2002), selenium, which has chemical properties extremely similar to sulfur, is metabolized in the same manner as sulfur and randomly incorporated into yeast cytosol, small-molecules like Se-glutathione, Se-adenosylhomocysteine (Uden et al. 2003) and proteins as Se-methionine (Tastet et al., 2008). Unlike yeast, mushrooms can metabolize selenium and can accumulate large quantities of it (Turlo et al., 2007) in the form of selenomethionine and selenocysteine. Animal feeding studies clearly showed that SelPlex ${ }^{\circledR}$ is not just a selenium source, but it also carries a variety of beneficial effects such as increased animal fertility (Rayman, 2000) or improved animal immune system activity (Rayman, 2000). Additionally, feeding SelPlex® to mice has been shown to delay the development of brain tumors from malignant human cancer cells implanted in mice brains (Toborek, 2011) and can significantly limit the deposition of $A \beta$ amyloid plaques in APP/PS1 mouse brains that carry human Alzheimer's disease genes (Lovell et al., 2009). 
Only some of these effects can be promoted by regular yeast cell wall preparations. However separating the bioactivities caused by the selenomethionine-containing yeast proteins from the activity caused by the polysaccharide parts of selenized yeast cell walls is difficult. Comparison of genomic activity in tissues taken from animals fed with SelPlex® to those fed with Bio-Mos ${ }^{\circledR}$ spiked with selenomethionine indicates very large differences in the regulation of multiple groups of genes for both treatments (Kwiatkowski et al., 2011), which may indicate that the bioactivity of Sel-Plex® involves cooperation between the selenoprotein and the polysaccharide components of selenized yeast cell walls.

Indeed, selected extracts from selenized yeast/yeast cell walls (Kwiatkowski et al., 2011) show potential as future, possible treatments of diseases such as type 2 diabetes, cancer and Alzheimer's.

\section{5. $\beta-(1 \rightarrow 3)(1 \rightarrow 6)$-D-glucan as valuable by product from yeast fermentation}

The commercial source from which the bulk yeast cell wall polysaccharides (including $\beta$ glucan) are produced uses the same strains of yeast as are used in fuel alcohol production. Le Saffre/ADM, Lallemand, Enzyme Development (New York) and DSM Life Sciences (Delft) are the largest suppliers of yeast for fuel ethanol producers in the United States and the European Union. Major factors that affect yeast cell wall composition include yeast strain (Hahn-Hagerdal et al., 2005), growth conditions (growth medium, temperature, osmotic pressure, toxic metabolites) and the time of harvesting (Aguilar-Uscanaga \& Francois, 2003; Klis et al., 2002; Klis et al., 2006). Fuel alcohol fermentation is a high stress process (Devantier et al., 2005) and the cell walls of the yeast collected as its byproduct contain a high amount of $\beta$-glucans (Basso et al., 2008; Knauf \& Kraus, 2006; Jones \& Ingledew, 1994). In general, yeast strains of Saccharomyces cerevisiae that are used in baking (baker's yeast) have a higher $\beta$-glucan-to- $\alpha$-mannan ratio than those that are used for alcohol fermentation (brewer's yeast), therefore it is advantageous to use pure baker's yeast for producing high quality $(1 \rightarrow 3)(1 \rightarrow 6)-\beta$-D-glucan for medicinal applications (Kim et al., 2007). The process of separating various yeast components has been heavily patented. However, the differences in the technologies are minor and in principle do not differ from the methodology described by Manners and Fleet (1976). The process starts from autolysing yeast cells at a temperature between $45^{\circ} \mathrm{C}$ and $65^{\circ} \mathrm{C}$ at slightly acidic $\mathrm{pH}$, to release yeast cell walls that are insoluble and denser than the cytoplasmic contents and can be separated by centrifugation (Wheatcroft et al., 2002). These steps can be followed by incubating the yeast cell walls with alkaline protease at a $\mathrm{pH}$ of 9 to 10 to solubilize mannans and leave behind insoluble $\beta$-glucan (Zapata et al, 2008), which can then be physically separated from the liquid fraction by centrifugation and subsequent washing (Sedmak, 2006). Additional enzymes, like glucoamylase and lipase, can be used to hydrolyze $\alpha$-glucan from $\alpha \beta$-glucan, which is still present in the cell wall material and to solubilize the residue lipids from cell membranes. The final step of $\beta$-glucan production is a spray-drying that produces a whiteto-maroon colored powder that does not carry any taste or aroma and is useful for feed and food applications. Further alkaline and acidic treatments of the food-grade $\beta$-glucan (Kelly, 
2001) yields high purity (98.5\% $\beta$-glucan, $<0.1 \%$ mannan, $0.4 \% \alpha$-glucan, $0.3 \%$ protein, $0.2 \%$ chitin) microparticulate $\beta$-glucan with reduced molecular weight (from 1-3 MDa to 150 $\mathrm{kDa}$ ) that is much more easily absorbed by the digestive tract and shows improved activity compared with food-grade products containing only $\sim 65 \% \beta$-glucan. Even further hydrolysis produces soluble yeast $\beta$-glucan (Jamas et al., 1998; Lee et al., 2001) that still retains most of the particular $\beta$-glucan bioactivities (Janusz et al., 1986; Wakshull et al., 1999).

Yeast Saccharomyces cerevisiae, its cell wall and products of its fractionation are generally recognized as safe (GRAS) by the US Food and Drug Administration (FDA, 1997), and they can be legally used as food ingredients but not as food additives. The European Food Safety Authority (EFSA) issued an opinion that yeast $\beta$-glucans are a "safe food ingredient" (EFSA, 2011) that can be used as a "food supplement" up to $375 \mathrm{mg} /$ day and in foods for "particular nutritional uses" at dose levels up to $600 \mathrm{mg} /$ day. (The uses of yeast cell wall as an animal feed ingredient were discussed in section 4 of this chapter).

Food-grade yeast $\beta$-glucans such as BetaRight ${ }^{\circledR}$ and WGP® (Biothera, Inc.) are used as ingredients in baked foods, beverages, ceral, yogurt, fruit juices, chocolate and as food thickeners in salad dressings, ice cream, mayonnaise, sauces and cheese. The majority of these applications have been patented (Zechner-Krpan et al., 2009; Thammakiti et al., 2004) and a critical review of 300 patented applications is available (Laroche \& Michaud, 2007). Yeast $\beta$-glucans improve food rheological properties, gelling, water and oil-holding properties, without impacting its taste or odor (Petravic-Tominac et al., 2011). Beta-glucans also add health benefits (Laroche \& Michaud, 2007) like antioxidative, bacteriostatic and immunostimmulating activities. Cosmetic products used in skin treatment contain yeast $\beta$ glucans as moisturizing and moisture-retaining components that also provide a proper moistening feeling. Because of its emulsion-stabilizing effects, pleasant texture and antioxidant activity yeast $\beta$-glucans can prevent skin injuries caused by solar radiation and therefore are used in sun-screens, oils and gels (Michiko \& Yutaka, 2007). Deodorants containing yeast $\beta$-glucans have proved to be useful in oral preparations, mouthwashes and diapers (Michiko et al., 2005). Acid-treated cell walls (AYC) can be used as new binders in pharmaceutical formulations and, when mixed with traditional fillers like hydroxypropylcellulose or polyvinylpyrrolidone, yield harder pills with very short ( $2 \mathrm{~min})$ dissolution times (Yusa et al., 2002). Its adhesive and biological properties can be also utilized in producing coating for surgical instruments (Klein, 2003) and in the manufacture of packaging for the food industry (Cope, 1987). Its antibacterial and antiviral properties have found application in the control of plant pests (Kitagawa, 2007) and viral invasions (Slovakova et al., 1997).

\section{Medicinal application of native and chemically modified forms of $\beta-(1 \rightarrow 6)(1 \rightarrow 3)-D-g l u c a n$}

Approximately 2000 research and review papers covering $\beta-(1 \rightarrow 6)(1 \rightarrow 3)$-D-glucan bioactivity and its medicinal applications have been published since the 1960's, and the 
majority of the literature has been reviewed (Bohn \& BeMiller, 1995; Kogan, 2000; Zekovic et al., 2005; Vetvicka, 2011; http://www.betaglucan.org; and for patented applications see Laroche \& Michaud, 2007). Many early assumptions have been confirmed by more rigorous studies, and many others have been disproven. Many of the studies that initially showed promise utilized poorly purified and not sufficiently standardized samples of yeast cell wall glucan (Jaehrig et al., 2007; Vetvicka \& Vetvickova, 2007). Highly purified, insoluble, wholeglucan particles (WGP) with the size 2-4 $\mu \mathrm{m}$ (Yan et al., 2005), or soluble, yeast poly-(1 $\rightarrow 6)$ $\beta$-D-glucopyranosyl-(1 $\rightarrow 3)-\beta$-D-glucopyranose (PGG) with molecular weight $\sim 150 \mathrm{kDa}$ (Gawronski et al., 1999) is presently used in animal and human studies. Glucan samples used in earlier studies could contain significant quantities of (also) bioactive impurities like yeast mannoproteins or $\alpha$-glucans. The existence of a correlation between the $\beta-(1 \rightarrow 6)(1 \rightarrow 3)$ D-glucan structure and its bioactivity is well established having been confirmed by multiple animal and human studies (Novak \& Vetvicka, 2009). The WGP-glucan fate after oral administration and PGG-glucan after intravenous administration has been studied in animals (Vetvicka \& Vetvickova, 2008). Mammalian cells lack $\beta$-glucan, which is present in the cell wall of many infectious microbes. Thus, mammalian macrophages, which are present "on guard" in the cells lining the digestive track, recognize and bind purified $\beta$ glucan, but not the whole yeast cells (which have mannoproteins on the cell surface), via the dectin-1 receptor, which is a glucan-sensing receptor expressed on dectin a transmembrane protein. The macrophages transport $\beta$-glucan molecules to the spleen, bone marrow and lymph nodes where they are disintegrated into smaller, soluble, $\beta$-glucan oligosaccharides that are released back into the bloodstream. The circulating monocytes, macrophages, neutrophils, natural killer and dendritic cells (Chan et al., 2009) which possesses $\beta$-glucan recognizing receptors, including: toll like receptor 2 (TLR-2, Underhill et al., 1999), dectin-1 (Brown et al., 2007), complement receptor 3 (CR-3) (Ross et al., 1987) and lactosyl ceramide receptor, bind to the $\beta$-glucan molecules triggering the non-specific-innate immune response, including phagocytosis and production of proinflammatory factors (Qi et al., 2011). This mechanism leads to the elimination of infectious agents (Chan et al., 2009). Cancer cells are recognized by the host immune system, but antibody response is too weak to destroy them. When humanized, anti-cancer monoclonal antibodies are used in cancer therapy the treatments are not uniformly effective. Combined antitumor monoclonal antibodies (mAb's) and $\beta$-glucan therapy yields much better results with fewer adverse side effects (Salvador et al., 2008; Liu et al., 2009). The mechanism of action is only partially understood with neutrophils and macrophages playing a role in the process of killing cancer cells (Liu et al., 2009). Strengthening immunity to various diseases (Hofer \& Pospisil, 2011) and combating those that are already active in humans and animals are the main applications of yeast $\beta$-glucan. In Eastern culinary tradition, eating mushrooms (which contain large quantities of soluble $\beta$-glucan in their fruiting bodies) has long been recognized as healthy, and four pharmaceutical preparations, based on mushroom extracts, have been registered as drugs in Japan (Hyodo et al., 2005). In the Western world several clinical trials (Babineu et al., 1994; Weitberg, 2008; Spruijt et al., 2010) proved the beneficial properties of WGP and PGG glucans, which are still waiting to be registered as drugs (Vetvicka, 2011; Lehtovaara \& Gu, 2011). The following therapeutic activities of yeast $\beta$ - 
glucan are well-established in treating the following conditions: post-surgical infections, hospital pneumonia, acute renal failure (Koc et al., 2011), pressure ulcers (bed sores), wound healing (surgical and as result of injury, Spruijt et al., 2010) and burns caused by heat, UV or $\mathrm{X}$-ray radiation. As an adjuvant yeast $\beta$-glucans alleviate stress and improves the mAb's plus PGG anticancer treatment for breast, colorectal, colon, leukemia, lung, ovarian and skin cancers, chemotherapy and radiotherapy; antireumatic drug therapy (Sener et al., 2006), and antifungal therapies. They stimulate bone marrow healing and bone repair (due to injuries), which increases red blood cell count and neutrophil production. Many of these activities were studied in the 1990s and 2000s and have been reviewed. Studies since 2010 have been referred to herein.

Some of the negative side effects that have been observed in response to prolonged or large doses of $\beta$-glucan preparations are the consequences of their mode of action as well as their physical and chemical properties. Their therapeutic activity is based upon immune system mobilization and the production of monocytes, macrophages, neutrophils, natural killer and dendritic cells which fight and destroy pathogens. However, prolonged pro-inflammatory changes in cells can cause the development of autoimmune diseases. The human body is missing enzymes that can hydrolyze $\beta$-glucan polysaccharides and for their degradation uses less efficient oxidative pathways. This insufficiency extends the cellular half-life of WGP and PPG glucans and can lead to the formation of granulomas in the liver, causing inflammation that can result in liver cirrhosis. Therefore the use of soluble and relatively low molecular weight PGG glucan is recommended. The well documented $\beta$-glucan abilities to lower blood sugar and blood pressure justify further study aimed at producing a glucan material with molecular weight lower than that of PGG glucan to preclude accumulation in granulomas, when used as a long-term food additive. The next stage of development of less toxic, soluble $\beta$-glucan preparations should include its size fractionation to produce more standardized material for medicinal applications. The majority of in vivo studies on $\beta$-glucan medicinal applications were done using rodent models, therefore it is easy to foresee veterinary applications of this food/feed ingredient to improve immune systems, facilitate burn and wound healing, stimulate post-trauma bone repair and help fight cancers.

\section{Author details}

Stefan Kwiatkowski

Alltech Inc. Nicholasville KY, USA

Stefan Edgar Kwiatkowski

University of Kentucky, USA

\section{Acknowledgement}

The author expresses deep gratitude to Dr. Pearse T. Lyons, President, and Dr. Karl Dawson, CSO, Alltech Inc. for their continuing support and inspiration. 


\section{References}

Aimaniada, V., Clavaud, C., Simenel, C., Fontaine, T., Delepierre, M. \& Latage, J-P. (2009). Cell wall $(1 \rightarrow 6)-\beta$-D-glucan of Saccharomyces cerevisiae - structural characterization and in situ synthesis, The Journal of Biological Chemistry Vol. 284: 13401-13412.

Aguilar-Uscanaga, B., \& Francois, J.M. (2003). A study of the yeast cell wall composition and structure in response to growth conditions and mode of cultivation, Letters in Applied Microbiology Vol. 37: 268-274.

Albright, J.D. \& Goldman, L. (1967). Dimethyl sulfoxide-acid anhydride mixtures for oxidation of alcohols, Journal of the American Chemical Society Vol. 89: 2416.

Arvindekar, A.U. \& Patil, N.B., (2002). Glycogen - a covalently linked component of the cell wall in Saccharomyces cerevisiae, Yeast Vol. 19(No. 2): 131-139.

Babineau, T.J., Marcello, P., Swails, W., Keuler, A., Bistrian, B. \& Forse, A. (1994). Randomized Phase I/II Trial of a Macrophage-Specific Immunomodulator (PGGGlucan) in High Risk Surgical Patients, Annals of Surgery Vol. 220(No. 5): 601-609.

Bacon, J.S.D., Farmer, V.C., Jones, D. \& Taylor I.F. (1969). The glucan components of the cel wall of Baker's Yeast (Saccharomyces cerevisiae) considered in relation to its ultrastructure, Biochemistry Journal Vol. 114: 557-567.

Ballou, C.E. (1980). Genetics of mannoprotein biosynthesis" in Fungal Polysaccharides, Sandford, P., et al; ACS Symposium Series; American Chemical Society: Washington D.C. $(1980)$ p 1-14.

Basso, L.C., de Amorim, H.V., de Oliveera, A.J. \& Lopes, M.L. (2008). Yeast selction for fuel alcohol production in Brazil, FEMS Yeast Research Vol. 8(No. 7): 1155-1163.

Baxter, E.W. \& Reitz, A.B. (2002). Reductive aminations of carbonyl compounds with borohydride and borane reducing agents, Organic Reactions Vol. 59: 1. Wiley: New York 2002.

Baurhoo, B., Ferket, P.R. \& Zhao, X. (2009). Effects of diets containing different concentrations of mannooligosaccharides or antibiotics on growth performance, intestinal development, cecal and litter microbial populations, and carcass parameters in broilers, Poultry Science Vol. 88(No.11): 2262-2272.

Bennet, J.W. \& Klich, M. (2003). Mycotoxins, Clinical Microbiology Reviews. Vol. 16(No. 3), 497-516.

Borchers, A.T., Keen, C.L. \& Gershwin, M.E.et al. (2004). Mushrooms, tumors and immunity: an update, Experimental Biology and Medicine Vol. 229(No. 5): 393-406.

Bohn, J.A. \& Be Miller, J.N. (1995). (1 $\rightarrow 3)(1 \rightarrow 6)-\beta$-D-Glucans as biological response modifiers: a review of structure-functional activity relationships, Carbohydrate Polymers Vol. 28(No. 1): 3-14.

Brady, D., Stoll, A.D. \& Duncan, J.R. (1994). Chemical and enzymatic extraction of heavy metal binding polymers from isolated cell walls of Saccharomyces cerevisiae, Biotechnol. Bioeng. (USA) Vol. 44(No.3), 297-302.

Brown, J., O'Callaghan, Ch., Marshall, A.S.J., Gilbert, R.J.C., Siebold, Ch., Gordon, S., Brown, G.D. \& Jones, Y.J. (2007). Structure of the fungal $\beta$-glucan binding receptor dectin-1: implications for function, Protein Science Vol. 16: 1042-1052. 
Chan, G.Ch-F., Chan, W.K. \& Sze, D.M-Y. (2009). The effects of $\beta$-glucan on human immune and cancer cells, Journal of hematology $\mathcal{E}$ oncology Vol. 2: 25.

Cope, Roy (1987) Adhesive substances from yeast cell wall, Eur. Pat. Appl. EP 230378 A2.

Dake, M.S., Jadhv, J.P. \& Patil, N.P. (2010). Variations of two pools of glycogen and carbohydrate in Saccharomyces cerevisiae grown with various ethanol concentrations, Journal of Industrial Microbiology \& Biotechnology Vol. 37(No. 7): 701-706.

Demirici, A. \& Pometto III, A.L. (1999). Production of organically bound selenium yeast by continuous fermentation, J. Agric. Food Chem. Vol. 47(No. 6): 2491-2495.

Demirici, A., Pometto III, A.L. \& Cox, D.J. (1999). Enhanced organically bound selenium yeast production by fed-batch fermentation, J. Agric. Food Chem. Vol. 47(No. 6): 24962500 .

Devantier, R., Pedersen, S. \& Olsson, L. (2005). Characterization of very high gravity ethanol fermentation of corn mash. Effect of glucoamylase dosage, pre-saccharification and yeast strain, Appl Microbiol Biotechnol Vol. 68: 622-629.

Dimitroglu, A., Merrifield, D.A., Moate, R., Davies, S.J., Spring, P., Sweetman, J. \& Bradley, G. (2009). Dietary mannan oligosaccharide supplementation modulates intestinal microbial ecology and improves gut morphology of rainbow trout, Oncorhynchus mykiss (Walbaum), Journal of Animal Science Vol. 87(No. 10): 3226-3234.

Dvorska, J.E. \& Surai, P.F. (2003). Protective effect of modified glucomannans against aurofusarin induced changes in quail egg and embryo" Asian-Australian Journal of Animal Science Vol.17(No.3): 434-440.

Ebina, T., Kubota., Ogama, N. \& Matsunaga, K. (2002). Antitumoreffect of a peptide-glucan preparation extracted from a mycelium of Tricholoma matsutake (S. Ito and Imai) Sing, Biotherapy Vol. 16(No. 3): 255-259.

EFSA. (2011) Scientific opinion on the safety of 'yeast $\beta$-glucans' as novel food ingredient, EFSA Journal Vol. 9(No. 5): 2137-2159.

FDA. (1997) Substances generally recognized as safe, Federal Register 62 FR 18938, 17 April 1997.

Garcia, I., Tajadura, V., Martin, V., Toda, T. \& Sanchez, Y. (2006). Synthesis of $\alpha$-glucans in fission yeast spores is carried by three $\alpha$-glucan synthase paralogs Mok12p, Mok13p and Mok14p, Molecular Microbiology Vol. 59(No. 3): 836-853.

Gawronski, M., Park, J.T., Magee, A.S. \& Conrad, H. (1999). Microfibrillar structure of PGG glucan in aqueous solution as triple helix aggregates by small angle x-ray scattering, Biopolymers Vol. 50: 569-578.

Grba, S., Oura, E. \& Soumalainen, H. (1976). Formation of glycogen and trehalose in baker's yeast, European Journal of Applied Microbiology Vol. 2(No. 1): 29-37.

Grube B.J., Eng, E.T., Kao, Y.C., Kwon, A. \& Chen, S. (2001). White button mushroom phytochemicals inhibit aromatase activity and breast cancer cell proliferation, $J$. Nutrition Vol. 131(No. 12): 3288-93.

Grün, Ch.H., Hochstenbach, F., Humbel, B.M., Verkleij, A.J., Sietsma, J.H., Klis, F.M., Kamerling, J.P. \& Vliegenthart, J.F.G. (2005). The structure of cell wall $\alpha$-glucan from fission yeast, Glycobiology Vol. 15(No. 3): 245-257.

Gunia-Smith, Z., Patil, N.B. \& Smith, E.E., (1977). Two pools of glycogen in Saccharomyces, Journal of Bacteriology Vol. 1977: 818-825. 
Hahn-Hagerdal, B., Karhumaa, K., Larsson, Ch.U., Gorwa-Grauslund, M., Gorgens, J. \& van Zyl, W.H. (2005). Role of cultivation media in the development of yeast strains for large scale industrial use, Microbial Cell Factories Vol. 4: 31-47.

Hirotaka, H., Yoko, Y., Kenichi, M., Yoko, I. \& Tdeshi, Y. (2007). Development of enzymelinked immunoassay to detect immunomodulatory $\alpha$-D-glucan-protein complex, MPG1, in basidiomycete Tricholoma matsutaka and related processed food, J. Agric. Food Chem. Vol. 55(No. 21): 8508-8515.

Hirotaka, H., Yoko, Y., Kenichi, M., Yoko, I. \& Tdeshi, Y. (2005). Isolation and characterization of a novel immunomodulatory $\alpha$-glucan-protein complex from the mycelium of Tricholoma matsutake in basidiomycetes, J. Agric. Food Chem. Vol. 53(No. 23): 8948-8956.

Hofer, M. \& Pospisil, M. (2011). Modulation of animal and human hematopoiesis by $\beta$ glucans: a review, Molecules Vol. 16: 7969-7979.

Holliday J., Cleaver, M. (2008). Medicinal Value of the Caterpillar Fungi Species of the Genus Cordyceps (Fr.) Link (Ascomycetes), International Journal of Medicinal Mushrooms Vol. 10(No. 3): 219

Huang, D., Farkas, I. \& Roach, P.J. (1996). Pho85p, a cyclin-dependent protein kinase, and the Snf1p protein kinase act antagonistically to control glycogen accumulation in Saccharomyces cerevisiae, Molecular and Cellular Biology Vol. 16(No. 8): 4357-4365.

Hutchins, K. \& Bussey, H. (1983). Cell wall receptor for yeast killer toxin: involvement of (1, 6)- $\beta$-D-glucan, Journal of Bacteriology Vol. 154: 161-169.

Hyodo I., Amano, N., Eguchi, K., Narabayashi, M., Imanishi, J., Hirai, M., Nakano, T. \& Takashima S. (2005). Nationwide survey on complementary and alternative medicine in cancer patients in Japan, Journal of Clinical Oncology Vol. 23(No. 12): 2645-54.

Jacques, K.A. \& Newman, K.E. (1994). Effect of oligosaccharide supplements on performance and health of Holstein calves pre- and post-weaning, Journal of Animal Science Vol. 72(Suppl. 1): 295.

Jadhav, J.P. Dake, M.S. \& Patil, N.P. (2008). $\alpha, \beta$-Glucan complex in Saccharomyces carlsbergensis, Asian Journal of Chemistry Vol. 20(No. 1): 55-65.

Jaehrig, S.C., Rohn, S., Kroh, L.W. Fleisher, L-G. \& Kurtz, T. (2007). In vitro potential antioxidant activity of $(1 \rightarrow 3) \quad(1 \rightarrow 6)-\beta$-D-glucan and protein fractions from Saccharomyces cerevisiae cell walls, J. Agric. Food Chem. Vol. 55(No. 12): 4710-4716.

Jamas, S., Easson Jr, D.D. \& Ostroff, G.R. (1997). Glucan preparation, US Patent US 5622939, Apr 22, 1997.

Jamas, S., Easson Jr, D.D. \& Ostroff, G.R. (1998). Underivatized, aqueous soluble $\beta$ - $(1,3)-$ glucan, composition and making some, US Patent US 5817643, Oct 6, 1998.

Janusz, M.J., Austen, K.F. \& Czop, J.K. (1986). Isolation of soluble yeast beta-glucan that inhibit human monocyte phagocytosis mediated by beta-glucan receptors, The Journal of Immunology Vol.137 (No. 10):3270-3276.

Jones, A.M. \& Ingledew, W.M. (1994). Fuel alcohol production: optimization of temperature for very efficient very-high gravity fermentation, Applied and Environmental Microbiology Vol. 1994: 1048-1051. 
Kakutani, R., Adachi, Y., Kajiura, H., Takata, H., Kuriki, T. \& Ohno, N. (2007). Relationship between structure and immunostimulating activity of enzymatically synthesized glycogen, Carbohydrate Research Vol. 342: 2371-2379.

Kaptein, J.C., Van Den Ende, H. \& Klis, F.M. (1999). The contribution of cell wall proteins to the organization of the yeast cell wall, Biochimical Biophysical Acta-General Subjects Vol. 1426(No. 2): 373-383.

Karaman, M., Basmocioglu, H., Ortatatli, M. \& Oguz, H. (2005). Evaluation of detoxifying effect of yeast glucomannan on aflatoxicosis in broilers as assessed by gross examination and histopathology, British Poultry Science Vol. 46(No. 3): 394-400.

Kath, F. \& Kulicke, W-M. (1999). Mild enzymatic isolation of mannan and glucan from yeast Saccharomyces cerevisiae, Die Angewandte Makromoleculare Chemie Vol. 268: 59-68.

Kelly, G.E., (2001) Process for glucan preparation and therapeutic uses of glucan, US Patent US 6,242,594 B1.

Khan, M.A., Mousumi, T., Dian-Zheng Zhang \& Han-Chun Chen (2010). Cordyceps Mushroom: A Potent Anticancer Nutraceutical, The Open Nutraceutical Journal Vol. 3: 179-183.

Kiho, T., Hui, J., Yamane A. \& Ukai S. (1993). Polysaccharides in fungi. XXXII. Hypoglycemic activity and chemical properties of a polysaccharide from the cultural mycelium of Cordyceps sinensis, Biol. Pharm. Bull. Vol. 16(No. 12): 1291-1293.

Kiho, T., Hui, J., Yamane A. \& Ukai S. (1996). Polysaccharides in fungi. XXXVI. Hypoglycemic activity of a polysaccharide (CS-F30) from the cultural mycelium of Cordyceps sinensis and its effect on glucose metabolism in mouse liver, Biol. Pharm. Bull. Vol. 19(No. 2): 294-296.

Kim, Y-H., Kang, S.W., Lee, J.H., Chang, H-I., Yun, Ch-W., Paik, H-D., Kang, Ch-W. \& Seung, W. (2007). High density fermentation of Saccharomyces cerevisiae JUL3 in fedbatch culture for the production of $\beta$-glucan, Journal of Industrial and Engineering Chemistry (Seoul) Vol. 13(No. 1): 153-158.

Kitagawa, T. (2007). Yeast cell wall degradation product as plant pest control agent, Jpn. Kokai Tokkyo Koho JP 2007045708 A.

Klein, B (2003). Immunostimulating coating for surgical devices, US Patent US 6541678 B2.

Klis, FM., Mol, P., Hellingwerf, K. \& Brul S. (2002) Dynamics of cell wall structure in Saccharomyces cerevisiae, FEMS Microbiology Reviews Vol. 26(No. 3): 239-256.

Klis, F.M., Boorsma, A. \& DeGroot, P.W.J. (2006). Cell wall construction in Saccharomyces cerevisiae, Yeast Vol. 23: 185-202.

Knauf, M. \& Kraus, K. (2006). Specific yeast developed for modern ethanol production, Sugar Industry Vol. 131: 753-758.

Koc, E., Reis, K.A., Ebinc, F.A., Pasaoglu, H., Demirtas, C., Omeroglu, S., Derici, U.B., Erten, Y., Bali M., Arinsov, T. \& Sindel, S. (2011). Protective effect of beta-glucan on contrast induced-nephropathy [acute renal failure] and a comparison of beta-glucan with nebivolol and N-acetylcysteine in rats, Clin. Exp. Nephrol.Vol. 15(No. 5): 658-665.

Kogan, G. (2000). $(1 \rightarrow 3,1 \rightarrow 6)-\beta$-D-Glucans of yeast and fungi and their biological activity, Studies in Natural Products Chemistry Vol. 23: 107-151/Atta-ur-Rahman (Ed.) Elsevier 2000. 
Kogan, G. \& Koher, A. (2007). Role of yeast cell wall polysaccharides in pig nutrition and health protection, Livestock Sci. Vol. 109: 161-165.

Kogan, G., Pajtinka, M., Babincova M., Miadokova, E., Ranko, P., Slamenova, D. \&

Korolenko, T.A., (2008).Yeast Cell Wall Polysaccharides as antioxidants and antimutagens: can they fight cancer? Neoplasma Vol. 55: 5.

Kojima, H., Akaki, J., Nakajima, S., Kamei, K. \& Tamesada, M. (2010). Structural analysis of glycogen like polysaccharides having macrophage-activating activity in extracts, J. Nat. Med. Vol. 64:16-23.

Kollar, R., Reinhold, B.B., Petrakova, E., Yeh, H.J.Ashwell, G., Drgonova, J., Kaptein, J.C.,

Klis, F.M. \& Cabib E., (1997). Architecture of the yeast cell wall $\beta$-(1-6)-glucan interconnects mannoprotein, $\beta-(1-3)$ glucan and chitin, The Journal of Biological Chemistry Vol. 272(No. 28): 17762-17775.

Koppada, R., Norozian, F. N., Torbati, D., Kalomiris Sophia, Ramachandran, Ch. \& Totapally B.R. (2009). Physiological effects of a novel immune stimulator drug $(1 \rightarrow 4)-\alpha-$ D-glucan in rats, Basic and Clinical Pharmacology and Toxicology Vol. 105(No. 4): 217-221.

Krizkova L., Zitnanova, I., Mislovicova, D., Masarova, J., Sasinkova, V., Durackova, Z. \& Krajovic, J. (2006). Antioxidant and antimutagenic activity of mannan neoglycoconjugates: mannan-human serum albumin and mannan-penicilin $\mathrm{G}$ acylase, Mutation Research/Genetic Toxycology and Environmental Mutagenesis Vol. 606(No. 1-2): 72-79.

Kwiatkowski S., Thielen, U., Glenny, P. \& Moran, C. (2009). A study of Saccharomyces cerevisiae cell wall glucans, The Institute of Brewing \& Distilling Vol. 115(No. 2):151-158.

Kwiatkowski, S., Powers, R., Matney, C., Ghorghchian, P.P. \& Ostertag, E.M. (2011). Compositions and methods for separating, characterizing and administering selenoglycoproteins, USPTO Application: 20110280948.

Laroche, C. \& Michaud, P. (2007). New developments and perspective applications for $\beta$ - (1, 3)-glucans, Recent Patents on Biotechnology Vol. 2007(No. 1): 59-73.

Lavi, I., Friesem, D., Geresh, S., Hadar, Y. \& Schwartz, B. (2006). An aqueous polysaccharide extract from the edible mushroom Pleurotus ostreaus induces antiproliferative and proapoptotic effects on HT-29 colon cancer cells, Cancer Letters (Amsterdam, Netherlands) Vol. 244(No. 1): 61-70.

Lee, J.N., Lee, D.Y., Kim, G.E., Kim, H.N., Sohn, J., Kim, S. \& Kim, C.W. (2001). Purification of soluble beta-glucan with immune-enhancing activity from cell wall of yeast, Biosci. Biotechnol. Biochem. Vol. 65(No. 4): 831-841.

Lei, H., Ma, X. \& Wu, W. (2007). Anti-diabetic effect of $\alpha$-glucan from fruiting body of maitake (Grifola frondosa) on KK-Ay mice, Journal of Pharmacy and Pharmacology Vol. 59(No. 4): 575-582.

Lehtovaara, B.C. \& Gu, F.X. (2011). Pharmacological, Structural, and Drug Delivery Properties and Applications of 1, 3- $\beta$-Glucans, J. Agric. Food Chem. Vol. 59(No. 5): 68136828.

Lessage, G. \& Bussey, H. (2006). Cell wall assembly in Saccharomyces cerevisiae, Microbiology and Molecular Biology Reviews Vol. 70(No. 2): 317-343. 
Leung, M.C.K., Diaz-Llano, G. \& Smith, T.K. (2006). Mycotoxins in pet food: a review on worldwide prevalence and preventive strategies, J. Agric. Food Chem. Vol. 54 (No. 26): 9623-9635.

Li, S.P., Zhang, G.H., Zeng, Q., Huang, Z.G., Wang, Y.T., Dong, T.T.X \& Tsim, K.W.K. (2006). Hypoglycemic activity of polysaccharide, with antioxidation, isolated from cultured Cordyceps mycelia, Phytomedicine Vol. 13(No. 6): 428-433.

Li H., Lu, X., Zhang, S., Lu, M. \& Liu, H. (2008). Anti-inflammatory activity of polysaccharide from Pholiota nameko, Biochemistry (Moscow) Vol. 73(No. 6): 669-675.

Lichtenthaler, F.W. \& Peters, S. (1980). Carbohydrates as green raw materials for the chemical industry, Comptes Rendus Chimie Vol. 7(No. 2): 65-90.

Lille, S.H. \& Pringle, J.R. (1980). Reserve carbohydrate metabolism in Saccharomyces cerevisiae: response to nutrition limitation, Journal of Bacteriology Vol. 143: 1384-1394.

Lindhorst, T.K. (2003). Essentials of carbohydrate chemistry and biochemistry, Wiley-VCH, Weinheim, ISBN 3-527-30664-1

Liu, J., Gunn, L., Hansen, R. \& Yan, J. (2009). Combined yeast derived $\beta$-Glucan with antitumor monoclonal antibody for cancer immunotherapy, Experimental and Molecular Pathology Vol. 86(No. 3): 208-214.

Liu, W-Ch., Wang, S-Ch., Tsai, M-L., Chen, M-C., Wang, Y-C., Hong, J-H., McBride W. \& Chiang, Ch-S. (2006). Protection against radiation-induced bone marrow and intestinal injuries by Cordyceps sinensis, a Chinese herbal medicine, Radiation Research Vol. 166(No. 6): 900-907.

Lovell, M.A., Xiong, S., Lyubartseva, G. \& Markesbery, W.R. (2009). Organo-selenium (Sel Plex) decreases amyloid burden and RNA and DMA oxidative damage in APP/PS1 mice, Free. Radic. Biol. Med. Vol. 46(No. 11): 1527-1533.

Mach C.M., Fugii, H., Wakame, K. \& Smith, J. (2008). Evaluation of active hexose correlated compound hepatic metabolism and potential for drug interactions with chemotherapy agents, Journal of the Society for Integrative Oncology Vol. 6(No. 3): 105-9.

Manners, D.J. \& Fleet, G.H. (1976). Isolation and composition of alkali soluble glucan from cell walls of Saccharomyces cerevisiae, J. Gen. Microbiol. Vol. 94: 180-192.

Manners, D.J., Masson, A.J., Patterson, J.C., Bjorndal, H. \& Lindberg L., (1973) The structure of $\beta-(1 \rightarrow 6)-D-g l u c a n$ from Yeast cell wall, Biochemical Journal Vol. 135: 19-30.

Mansour, M.K. \& Levitz S.M. (2003). Fungal mannoproteins: the sweet path to immunodominance, ASM News Vol. 69 (No. 12): 595-560.

Mapelli, V., Hillestrom, P.R., Kapolna, E., Larsen, E.H. \& Olsson, L. (2011). Metabolic and bioprocess engineering for production of selenized yeast with increased content of seleno-methylselenocysteine" Metabolic Engineering Vol. 13(No. 3): 282-293.

McLean J.E. \& Bledsoe B.E. (1992). Behavior of metals in soils, EPA Ground Water Issue 1992, EPA/540S-92/018.

Michiko, Y., Tomohiko, N. \& Yutaka, K. (2005). Deodorants containing yeast cell wall fraction, Jpn. Kokai Tokkyo Koho JP 2005325065 A.

Michiko, Y. \& Yutaka, K. (2007) Skin conditioning composition containing cell wall fractions, JP 2007045714 Feb 22, 2007.

Moran, C., Kwiatkowski, S., Yannikouris, A. \& Thielen, U. (2011). Yeast cell wall components and detection thereof, International Patent Application WO 2011143613 (A1) 20-11-17. 
Morrison S.J., Dawson, S. \& Carson, A.F. (2010). The effects of mannan oligosaccharide and Streptococcus faecium addition to milk replacer on calf health and performance, Livestock Science Vol. 131(No. 2): 292-296.

Novak, M. \& Vetvicka, V. (2009). Glucans as biological response modifiers, Endocrine, Metabolic and Immune Disorders-Drug Targets Vol. 9: 67-75.

Ohno, N., Mimura, H., Suzuki, I. \& Yadomae, T. (1985). Antitumor activity and structural characterization of polysaccharide fractions extracted with cold alkali from a fungus, Peziza vesiculosa, Chem. Pharm. Bull. (Tokyo) Vol. 33(No. 6): 2564-8.

Osumi, M. (1998) The ultrastructure of yeast: cell wall structure and formation, Micron Vol. 29: 207-233.

Patel, G.B. \& Ingledew, W.M. (1975). The relationship of acid soluble glycogen to yeast flocculation, Can. J. Microbiol. Vol. 21: 1608-1613.

Petravic-Tominac V., Zechner-Krpan, V., Berkovic, K., Golovic, P. Hercog, Z., Srecec, S. \& Spoliaric, I. (2011). Rheological properties, water-holding and oil-binding capacities of particulate $\beta$-glucans isolated from spent Brewer's yeast by three different procedures, Food Technol. Biotechnol. Vol. 49(No. 1): 56-64.

Qi, C., Cai, Y., Ding, Li. B., Kloecker, G., Qian, K., Vasilakos, J., Saijo, S., Iwakura, Y., Yannelli, J.R. \& Yan, J. (2011). Differential pathways regulating innate and adaptive antitumor immune responses by particulate $\beta$-glucan, Blood Vol. 117(No. 25): 6825-6836.

Quain, D.E. (1981). The determination of glycogen in yeast, J.Inst.Brew. Vol. 87: 289-291.

Rayman, M.P. (2000). The importance of selenium to human health, Lancet Vol. 356: 233-241.

Raymond, S.L., Smith, T.K. \& Swamy H.V.L.N. (2003). Effects of feeding a blend of grains naturally contaminated with Fusarium mycotoxins on feed intake, serum chemistry and hematology of horses and the efficacy of a polymeric glucomannan mycotoxin adsorbent, J. Anim. Sci. Vol. 81: 2123-2130.

Ren Z., Guo, Z., Meydani, S.N. \& Wu, D. (2008). White button mushroom enhances maturation of bone marrow-derived dendritic cells and their antigen presenting function in mice, J.Nutrition Vol. 138 (No. 3): 544-50.

Rodrigo, M-J., Moskovitz, J., Salamini, F. \& Bartels, D. (2002). Reverse genetic approaches in plants and yeast suggest a role for novel, evolutionary conserved, selenoprotein-related genes in oxidative stress defense, Mol. Genet. Genomicks Vol. 267: 613-621.

Rop, O., Mlcek, J. \& Jurikova, T. (2009) Beta-glucans in higher fungi and their health effects, Nutrition Reviews Vol. 67 (No. 11): 624-31.

Rosen, G.D. (2007). Holo-analysis of the efficacy of Bio-Mos in pig nutrition, Animal Science Vol. 82: 683-689.

Ross, G.D., Cain, J.A., Moynes, B.L., Newman, S.L. \& Lachman, P.J. (1987). Role of complement receptor type three and serum opsonins in the neutrophil response to yeast, Complemment Inflamm. Vol. 4: 61-74.

Rothman-Denes, L.B. \& Cabib, E. (1970). Two forms of glycogen synthetase and their role in glycogen accumulation, P.N.A.S. Vol. 66: 967-974.

Salvador, C., Li, B., Haqnsen, R., Cramer, D.E., Kong, M \& Jun, Y. (2008). Yeast derived $\beta$ glucan augments the therapeutic efficacy mediated by anti-vascular endothelial growth factor monoclonal antibody in human carcinoma xenograft models, Clin. Cancer Res.Vol. 14(No. 4): 1239-1247. 
Sedmak, JJ. (2006). Production of $\beta$-glucans and Mannans, US Patent Application Nov 23, 2006 US 2006/0263415 A1.

Sener, G., Eksioglu-Demiraop, E., Cetiner, M., Ercan, F. \& Yegen, B.C. (2006). Beta-glucan ameliorates methotrexate-induced oxidative organ injury via its antioxidant and immunomodulatory effects, European J Pharmacology Vol. 542(No. 1-3): 170-178.

Shah, S.K., Walker, P.A., Moore-Olufemi, S.D., Sundaresan, A., Kulkarini, A.D. \& Andrassy, R.J. (2011). An evidence-based review of a Lentinula edodes mushroom extract as complementary therapy in the surgical oncology patient, Journal of Parenteral and Enteral Nutrition Vol. 35(No. 4): 449-58.

Shida, M. \& Matsuda, K. (1974). Studies on polysaccharides from Lentinus edodes (Shii-ta-ke), Mushroom Science Vol. 9(pt1): 531-539.

Slaughter, J.C. \& Nomura, T. (1992). Intracellular glycogen and trehalose contents as predictors of yeast viability, Enzyme and Microbial Technology Vol. 14(No. 1): 64-67.

Slovakova, L., Subikova, V., Sandula, J. \& Huncikova, S. (1997) An agent for preventive protection of plants from viral diseases, SK 278413 Apr 9, 1997.

Smiderle, F.R., Sassaki, G.L., Van Arkel, J., Jacomini, M., Wickers, H.J. \& Van Griensven, L.J.L.D. (2010). High molecular weight glucan of the culinary medicinal mushroom Agaricus bisporus in an $\alpha$-glucan that forms complexes with low molecular weight galactan, Molecules Vol. 15(No. 8): 5818-5830.

Smith, J.E., Solomons, G., Lewis, C. \& Anderson, J.G. (1995. Role of mycotoxins in human and animal nutrition and health, Natural Toxins Vol. 3(No. 4): 187-192.

Smits, G.J., van den Ende, H. \& Klis, F.M. (2001). Differential regulation of cell wall biogenesis during growth and development in yeast, Microbiology Vol. 147: 781-794.

Spruijt, N.E., Visser, T. \& Leenen, L.P.H. (2010). A systematic review of randomized controlled trials exploring the effect of immunomodulative interventions on infection, organ failure, and mortality in trauma patients, Crit. Care Vol. 14: R150.

Stewart G.G. \& Russell I. (1998). Brewer's Yeast, Brewing Science \& Technology Series III (1998): 28-46, The Institute of Brewing ISBN No. 0900489138.

Suzuki, I., Yadomae, T., Yonekubo, H., Nishijima, M. \& Miyazaki, T. (1982). Antitumor activity of an immunomodulating material extracted from a fungus, Peziza vesiculosa, Chem. Pharm. Bull. (Tokyo) Vol. 30(No. 3): 1066-8.

Swanson, K.S., Grieshop, C.M., Fuckinger, E.A., Bauer, U., Healy, H-P., Dawson, K.A., Merchen, N.R. \& Fahey Jr., G.C. (2002). Supplemental fructooligosaccharides and mannooligosaccharides influence immune function, ileal and total tract nutrient digestibilities, microbial populations and concentrations of protein catabolites in the large bowel of dogs, The Journal of Nutrition Vol. 132(No. 5): 980-989.

Tanaka, A. (2011). Blood glucose suppression effect of Maitake mushroom extract, BRAIN Techno News Vol. 146: 30-34.

Tapiero, H., Townsend, D.M. \& Tew, K.D. (2003). The antioxidant role of selenium and seleno-compounds, Biomedicine \& Pharmacotherapy Vol. 57: 134-144.

Tastet, L., Schaumloffel, D., Bouisierre, B. \& Lobinski, R. (2008). Identification of selenium containing proteins in selenium rich yeast aqueous extract by 2D gel electrophoresis, nanoHPLC-ICP MS and nanoHPLC-ESI MS/MS, Talanta Vol. 75: 1140-1145.

Terakawa, N., Matsui, Y. Satoi, S., Yanagimoto, H., Takahashi, K., Yamamoto, T., Yamao, Y., 
Takai, S., Kwon, A-Hon. \& Kamiyama, Y. (2008). Immunological effect of active hexose correlated compound (AHCC) in healthy volunteers: a double-blind, placebo-controlled trial, Nutrition and Cancer Vol. 60(No. 5): 643-51.

Thammakiti, S., Suphantharika, M., Phaesuwan, T. \& Verduyn, C. (2004). Preparation of brewer's yeast $\beta$-glucans for potential application in the food industry, International Journal of Food Science and Technology Vol. 39(No. 1): 21-29.

Toborek, M. (2011) University of Miami, USA, Private communication.

Turlo, J., Gutkowska, B. \& Malinowska, E. (2007). Relationship between the selenium, selenomethionine and selenocysteine in submerged cultivated mycelium of Lentinula edodes (Berk.), Acta Chromatographica Vol. 18: 36-48.

Tzianabos, A.O. (2000). Polysaccharide immunomodulators as therapeutic agents: structural aspects and biologic function, Clinical Microbiology Reviews Vol. 2000: 523-533

Uden, P.C., Boakye, H.T., Kahakachchi, C., Hafezi, R., Nolibos, P., Block, E., Johnson, S Tyson, J.F. (2003). Element selective characterization of stability and selectivity of selenium species in selenized yeast, J. Anal. At. Spectrom. Vol. 19: 65-73.

Underhill, D.M., Ozinsky, A., Hajjar, A.M., Stevens, A., Wilson, C.B., Bassetti, M. \& Andersen, A. (1999). The Toll like receptor 2 is recruited to macrophage phagosomes and discriminates between pathogens, Nature Vol. 401: 811-815.

Valarezo, S. (1998). Comparative effects of antibiotic, mannooligosaccharide and mycotoxin adsorbent on performance of commercial broilers fed pelleted diets, Poultry Science Vol. 77(Suppl. 1): 137.

Vetvicka, V. (2011). Glucan-immunostimulant, adjuvant, potential drug, World Journal of Clinical Oncology Vol. 2(No. 2): 115-119.

Vetvicka, V. \& Vetvickova, J. (2007). Physiological effects of different types of $\beta$-glucan, Biomed. Pap. Med. Fac. Univ. Palacky Olomouc. Czech Repub. Vol. 151(No. 2): 225-231.

Vetvicka, V. \& Vetvickova, J. (2008). A comparison of injected and orally administered $\beta$ glucans, JANA Vol. 11(No. 1): 42-49.

Villar-Tajadura M., Madrid, M., Casando, J., Santos, B. \& Perez, P. (2008). Rga2 is a Rho2 GAP that regulates morphogenesis and cell integrity in Saccharomyces pombe, Molecular Microbiology Vol. 70(No. 4): 867-881.

Vinogradov E., Petersen, B. \& Bock, K. (1998). Structural analysis of intact polysaccharide mannan from Saccharomyces cerevisiae yeast using ${ }^{1} \mathrm{H}$ and ${ }^{13} \mathrm{C}$ NMR spectroscopy at 750MHz, Carbohydrate Research Vol. 307(No. 1-2): 177-183.

Vos, A., Dekker, N., Distel, B., Leunissen, J.A.M. \& Hochstenbach, F. (2007). Role of the synthase domain of Ags1p in cell wall $\alpha$-glucan boiosynthesis in Fission Yeast, J. Biol. Chem. Vol. 282(No. 26): 18969-18979.

Wakshull, E., Brunke-Reese, D., Lindermuth, J., Fisette, L., Nathans, R.S., Crowley, J.J., Tufs, J.C., Zimmerman, J., Mackin, W. \& Adams, D.S. (1999). PGG-Glucan, a soluble $\beta-(1,3)-$ glucan enhances the oxidative burst response, microbial activity, and activities NF- $\kappa \mathrm{B}-$ like factor in human PMN: evidence for glycosphingolipid $\beta$-(1, 3)-glucan receptor, Immunopharmacology Vol. 41: 89-107.

Weitberg, A.B. (2008). A phase I/II trial of $\beta$-(1 $\rightarrow 3)(1 \rightarrow 6)$-D-glucan in the treatment of patients with advanced malignances receiving chemotherapy, J. Exp. Clin. Cancer Res. Vol. 27: 40-44. 
Wheatcroft, R., Kulandai, J., Gilbert, R.W., Sime, K.J., Smith, C.G. \& Langeris, W.H., (2002). Production of $\beta$-glucan-mannan preparations by autolysis of cells under certain $\mathrm{pH}$, temperature and time conditions, US Patent US 6444448 B1 Sep. 3, 2002.

Wellens, A., Garafalo, C., Nguyen, H., Van Gerven, N., Slattegard, R., Hernalsteens, J-P.,

Wyns, L., Oscarson, S., De Greve, H., Hultgren, S. \& Bouckaert, J. (2008). Intervening with urinary tract infections using anti-adhesives based on the crystal structure of the FimHoligomannose-3 complex, PLoS ONE Vol. 3(No. 4): e2040, 1-13.

Wilson, W.A., Wang, Z. \& Roach, P.J. (2002). Systematic identification of the genes affecting glycogen storage in the yeast Saccharomyces cerevisiae, Molecular \& Cellular Proteomics Vol. 1(No. 3): 232-242.

Wismar, R., Pedersen, S.B., Frokiaer, H. \& Laerke, H.N. (2010). Dietary fibers as immunoregulatory compounds in health and disease, Annals of the New York Academy of Sciences Vol. 1190: 70-85.

Yan, J., Allendorf, D.J. \& Bradley, B. (2005). Yeast whole glucan particle (WGP) $\beta$-glucan in conjunction with antitumor monoclonal antibodies to trat cancer, Expert Opin. Biol. Ther. Vol. 5: 691-702.

Yan, J-K., Wan, W-Q., Li, L. \& Wu, J-Y. (2011). Physicochemical properties and antitumor activities of two $\alpha$-glucans isolated from hot water extract of Cordyceps (CS-HKI) fungal mycelia, Carbohydrate Polymers Vol. 85(No. 4): 753-758.

Yang, Y., Iji, P., Kocher, A., Mikkelsen, L.L. \& Choct, M. (2008). Effects of mannooligosaccharide and fructooligosaccharide on the response of broilers to pathogenic Escherichia coli challenge, British Poultry Science Vol. 49(No. 5): 550-559.

Yannikouris, A., Francois, J., Poughon, L., Dussap, C-G., Bertin, G., Jeminet, G. \& Jouany, J. P. (2004). Alkali extraction of $\beta$-D-glucans from Saccharomyces cerevisiae cell wall and study of their absorptive properties toward Zeralenone, J. Agric. Food Chem. Vol. 52(No. 11): 3666-3673.

Yannikouris, A., Andre, G., Poughon, L., Dussap, C-G., Bertin, G., Jeminet, G. \& Jouany, J-P. (2006). Chemical and conformational study of the interactions involved in mycotoxins complexation with $\beta$-Glucans, Biomacromolecules Vol. 7(No. 4): 1147-1155.

Yusa, H., Katsuyama, H., Ozeki, T., Takashima, Y., Okada, H., Kasai, T., Eguchi, T. \& Kakiuchi, H. (2002). Application of acid treated yeast cell wall (AYC) as a novel binder, Yakuzaigaku Vol. 62(No. 4): 153-160.

Zapata, G.M., Meza, M. \& Meza Mendoza, H.A. (2008). Method for obtaining yeast glucan by autolysis of Saccharomyces cerevisiae Baker's yeast cells, PCT Int. Appl., WO2008032134 A1.

Zechner-Krpan, V., Petravic-Tominac, V., Panjkota-Krbavicic, I., Grba, S. \& Berkovic, K. (2009). Potential application of yeast $\beta$-glucans in food industry, Agriculturae Conspectus Scientificus Vol. 74(No. 4): 277-282.

Zekovic, D.B., Kwiatkowski, S., Vrvic, M. M., Jakovlievic, D. \& Moran, C. (2005). Natural and modified $(1 \rightarrow 3)-\beta$-D-glucans in health promotion and disease alleviation, Critical Reviews in Biotechnology Vol. 25(No. 4): 205-230.

Zekovic, D.B., Radulovic, M., Nastasovic, A., Vrvic, M.M., Jakovlievic, D. \& Kogan, G. (2006). Mild Pfitzner-Moffat oxidation of the $(1 \rightarrow 3)-\beta$-D-glucan from Saccharomyces cerevisiae, Chemical Papers Vol. 60(No. 3): 24-53. 